МОВНА ПРОФЕСІЙНА ТА ПРАКТИЧНА ПІДГОТОВКА
ФАХІВЦІВ ІЗ ПРИКЛАДНОЇ ЛІНГВІСТИКИ В УКРАЇНІ

\title{
LANGUAGE PROFESSIONAL AND PRACTICAL TRAINING OF APPLIED LINGUISTICS IN UKRAINE
}

У статті зроблено спробу проаналізувати зміст мовної просресійної та практичної підготовки фрахівців із прикладної лінгвістики в Україні на прикладі підготовки таких спеціалістів у Державному університеті «Житомирська політехніка». Авторка здійснює аналіз навчальних планів зі спеціальності «035.10. Філологія. Прикладна лінгвістика» на предмет поєднання фрілологічних навчальних дисциплін та дисциплін, які забезпечують підготовку з інфрормаційнокомп'ютерних технологій. У статті зазначено, що підготовка прикладних лінгвістів складається з трьох циклів: загальної підготовки, професійної підготовки та практичної підготовки. Своєю чергою перші два цикли поділяються на дві частини: навчальні дисципліни нормативної частини та навчальні дисципліни варіативної частини. Нами з'ясовано, що прикладна лінгвістика - че спеціальність, яка інтегрує професійне володіння іноземними мовами та знання інсоормаційно-комп'ютерних технологій і спрямована на розв'язання практичних завдань у галузі мовознавства, перекладознавства та інфрормаційних технологій. Доведено, що підготовка прикладних лінгвістів має складатися з ефективної підготовки з фрілологічних навчальних дисциплін та дисциплін, які забезпечують підготовку з інформаційно-комп'ютерних технологій, які в cmammi умовно названо IT-дисциплінами. З'ясовано, що для підготовки фрахівців з прикладної лінгвістики необхідно створювати інтегративні навчальні курси з урахуванням специфріки фрілологічних та ІТ-дисциплін, а також важливе застосування новітніх інформаційних технологій та запровадження дистанційного навчання під час їх вивчення. $У$ cmammi здійснено підрахунки відсоткового співвідношення навчального часу, виділеного на вивчення навчальних дисциплін нормативної та варіативної частини циклу загальної та професійної підготовки спеціальності «035.10. Філологія. Прикладна лінгвістика» у 2019/2020 н.р. Авторка узагальнює перелік закладів вищої освіти, у яких здійснюється підготовка прикладних лінгвістів в Україні. Крім того, дослідниця надає перелік закладів вищої освіти України, у яких вивчаються різні іноземні мови.
Ключові слова: мовна професійна підготовка, практична підготовка, при кладний лінгвіст, фрілологічні дисципліни, IT-дисципліни.

The article attempts to analyze the content of language professional and practical training of specialists in applied linguistics in Ukraine on the example of training of such specialists at Zhytomyr Polytechnic State University. The author analyzes the curricula in the specialty "035.10. Philology. Applied Linguistics" as a combination of philology and IT training. The article states that the training of applied linguists consists of three cycles: general training, vocational training and practical training. In turn, the first two cycles are divided into two parts: the disciplines of the normative and the variational parts. The researcher found that applied linguistics is a specialty that integrates professional knowledge of foreign languages and knowledge of information and computer technologies and aims to solve practical problems in the field of linguistics, translation and information technology. It has been proved that the training of applied linguists must consist of effective training in philological subjects and disciplines that provide training in information and computer technologies, which are conventionally referred to as IT disciplines. It has been found out that to prepare specialists in applied linguistics, it is necessary to create integrative training courses, taking into account the specifics of philological and IT disciplines, as well as the importan application of the latest information technologies and introduction of distance learning in their study. The article calculates the percentage of training time allocated for the study of the disciplines of the normative and variational part of the cycle of general and vocational training of the specialty "035.10. Philology. Applied Linguistics" in 2019/2020 academic year. The author summarizes the list of higher education institutions in which applied linguists are trained in Ukraine. In addition, the researcher provides a list of higher education institutions in Ukraine, in which different foreign languages are taught. Key words: language professional training, practical training, applied linguist, philological disciplines, IT-disciplines.
Постановка проблеми у загальному вигляді. Проблема підготовки прикладних лінгвістів не $€$ новою у світовій і вітчизняній освіті. Рефрормування національної вищої освіти в контексті сучасних євроінтеграційних процесів зумовлює потребу у врахуванні в процесі організації професійної підготовки вчителя європейських і світових стандартів. Спеціальність «Філологія. Прикладна лінгвістика» поєднує фрахове вивчення іноземних мов та сучасних інформаційно-комп'ютерних технологій, що $є$ надзвичайно перспективним на сучасному ринку праці.
Обсяг інфрормації, що зростає у світі 3 геометричною прогресією, вимагає фрахівця, який профресійно володіє не лише однією, переважно англійською, мовою, а декількома іноземними мовами, а також іншими професійними навичками, зокрема знаннями інорормаційно-комп'ютерних технологій. Тому сьогодні популярними є спеціальності, які інтегрують різні професійні компетентності.

Аналіз останніх досліджень і публікацій. Над загальними проблемами розвитку прикладної лінгвістики працюють як вітчизняні, так і зарубіжні мовознавці, серед яких А. Баранов, 
Н. Бардіна, Т. Брига, В. Корнієнко, 3. Партико, Е. Савенкова, О. Селіванова, Б. Коваль, Н. Городецький та інші. Серед зарубіжних дослідників питаннями прикладної лінгвістики займаються: Х. Фергюсон, В. Відовсон, М. Холідей, У. Чейф, Т. Гівон та інші.

Так, Т. Брига розглядає прикладну лінгвістику як повноправний розділ мовознавства, спрямований на розв'язання практичних завдань різних галузей науки й техніки, повсякденного життя людини, суспільства на підставі теоретичного доробку досліджень мови й мовлення [2, с. 11-16]. В. Корнієнко зупиняється на розвитку прикладної лінгвістики у контексті інтеграції наукових галузей [5].

Виділення не вирішених раніше частин загальної проблеми. Більшість науковців, які досліджують питання прикладної лінгвістики, зупиняються на проблемах їі розвитку як галузі мовознавства. Тим часом питання методики професійної підготовки прикладних лінгвістів як фахівців наразі залишаються поза увагою дослідників.

Метою статті є проаналізувати зміст професійної та практичної підготовки майбутніх прикладних лінгвістів як фрахівців.

Виклад основного матеріалу. Прикладна лінгвістика - це спеціальність, яка з'явилася 3 розвитком інформаційно-комп'ютерних технологій, спрямована на розв'язання практичних завдань у галузі мовознавства, перекладознавства та інфрормаційних технологій. Прикладна лінгвістика орієнтована на студентів, які прагнуть стати фрахівцями у сорері іноземної фрілології, глибоко володіти двома іноземними мовами (англійською та німецькою / фрранцузькою), мати фрундаментальні знання в галузі перекладознавства та лінгвістики, а також бути фахівцями 3 питань комп'ютерної обробки текстів природною мовою, використання інформаційно-пошукових та інфрормаційно-довідкових систем, забезпечувати переклад та ефрективний зв'язок 3 громадськістю [1]. Сучасний прикладний лінгвіст затребуваний у сорері економічних відносин та активізації ділових взаємин. Найважливішою характеристикою такого спеціаліста $€$ профресійне знання іноземних мов та вміння використовувати ці знання під час роботи з комп'ютерними програмами.

На нашу думку, спеціальність «Філологія. Прикладна лінгвістика», за класифрікацією І. Соколової [8], належить до підготовки фрілологів за двома неспорідненими спеціальностями. Підготовка таких фрахівців має складатися 3 ефективної підготовки 3 фрілологічних навчальних дисциплін та дисциплін, які забезпечують підготовку 3 інорормаційно-комп'ютерних технологій, які ми умовно назвемо ІТ-дисциплінами. При цьому необхідно зберігати баланс між дисциплінами загального та професійного циклу, а також практичною підготовкою прикладних лінгвістів.
За вимогою часу на ринку праці з'являються такі спеціальності, які поєднують різні галузі знань, такі як «менеджмент та іноземна мова», «математика та іноземна мова», «англійська мова і література та німецька мова і література» та інші [9, с. 23-26]. Для підготовки фрахівців за такими спеціальностями необхідно створювати інтегративні навчальні курси з урахуванням специфіки фрілологічних та IT-дисциплін, а також важливе застосування новітніх інформаційних технологій та запровадження дистанційного навчання під час їх вивчення.

Підготовка фрахівців за спеціальністю «Філологія. Прикладна лінгвістика» відома в Україні ще з середини 1990-х рр. Так, за довідником 1996/1997 н. р. підготовка за цією спеціальністю відбувалася у Харківському державному університеті (нині - Харківський національний університет імені В.Н. Каразіна) [10]. Тоді як у «Переліку напрямів (спеціальностей) та їх поєднання з додатковими спеціальностями і спеціалізаціями для підготовки педагогічних працівників-орілологів за освітньо-кваліфрікаційними рівнями бакалавра, спеціаліста, магістра» (2007) вищезазначена спеціальність не вказана [6]. 3 цього можемо зробити висновок, що після десятирічного досвіду підготовки спеціальність втратила актуальність. Проте в «Переліку спеціалізацій підготовки здобувачів вищої освіти ступенів бакалавра та магістра за спеціальністю “035. Філологія"», за якими здійснюється фрормування та розміщення державного замовлення, згідно з наказом МОН України (2016, 2018) була відновлена спеціальність під новим кодом «035.10. Прикладна лінгвістика» [7].

Проаналізуємо географрічні межі ЗВО (закладів вищої освіти), де готують прикладних лінгвістів. Підготовка фрахівців за неспорідненими спеціальностями відбувається у Київському національному лінгвістичному університеті, зокрема, «Мова та література (англійська мова) і психологія», «Переклад» (дві іноземні, мови), «Менеджмент організацій» (із знанням двох іноземних мов), «Правознавство» (зі знанням двох іноземних мов), «Інформатика» (з поглибленим вивченням англійської мови), «Прикладна лінгвістика», у Харківському національному педагогічному університеті імені Григорія Сковороди за даними 2007/08 н. р. була спеціальність «Інфрорматика (спеціалізація: англійська мова)».

За нашими спостереженнями, у 2016/2017 н. р. підготовка за спеціальністю «Філологія. Прикладна лінгвістика» здійснювалася у чотирьох державних 3ВО в Україні: Донецькому національному університеті імені Василя Стуса, Київському національному лінгвістичному університеті, Східноукраїнському національному університеті імені В. Даля, Харківському національному університеті імені В.Н. Каразіна [3, с. 316-330]. Тоді як у 2019/2020 н. р. коло ЗВО, які здійснюють таку 
підготовку, розширилося до 10, що свідчить про підвищення інтересу до цієї спеціальності через затребуваність прикладних лінгвістів на ринку праці (див. табл. 1).

До числа ЗВО, у яких здійснюється підготовка фахівців із прикладної лінгвістики, у 2019/2020 н. р. приєднався Державний університет «Житомирська політехніка», де вперше розпочалася така підготовка в Житомирській області.

Проаналізуємо цикли підготовки фрахівців зі спеціальності «Філологія. Прикладна лінгвістика» у 2019/2020 н. р. у Державному університеті «Житомирська політехніка». Так, навчальний план спеціальності поділяється на три цикли: загальної, професійної та практичної підготовки. Перші 2 цикли поділяються, відповідно, на 2 частини: нормативну та варіативну.

У нормативній частині циклу загальної підготовки майбутні прикладні лінгвісти вивчають такі дисципліни, як українська мова професійного спрямування, фрілософрія, політологія, психологія, загальне мовознавство, історія світової літератури, історія англійської мови, латинська мова, сучасні технології лінгвістичних досліджень, вища математика, основи інформаційних технологій. Тобто тут вивчаються як загальнонаукові дисципліни, так і фрілологічні, а також дисципліни, притаманні підготовці майбутніх програмістів (див. табл. 2).

Варто зазначити, що навчання в університеті орієнтоване на те, щоб задовольнити індивідуальні потреби студента, всебічно розвинути його здібності. У варіативній частині циклу професійної підготовки студент має змогу вибрати дисципліни 3 двох блоків. Так, згідно з навчальним планом студент обирає 9 кредитів за умови збереження тижневого навантаження і має право замінити їх курсами інших спеціальностей (див. табл. 3).

Проаналізуємо цикл профеесійної підготовки прикладних лінгвістів. У нормативній частині циклу відсоткове співвідношення між орілологіч-

Перелік ЗВО, у яких здійснюється підготовка за спеціальністю

Таблиця 1 «Філологія. Прикладна лінгвістика» у 2019/2020 н. p.

\begin{tabular}{|c|l|}
\hline № & \multicolumn{1}{|c|}{ ЗАКЛАД ВИщої ОСвІтИ } \\
\hline 1 & Державний університет «Житомирська політехніка» \\
\hline 2 & Донецький національний університет імені Василя Стуса \\
\hline 3 & Київський національний лінгвістичний університет \\
\hline 4 & Львівський національний університет ім. Івана Франка \\
\hline 5 & Національний аерокосмічний університет ім. М.Є. Жуковського «Харківський авіаційний інститут» \\
\hline 6 & Східноєвропейський національний університет імені Лесі Українки \\
\hline 7 & Ужгородський національний університет \\
\hline 8 & Університет імені Альфреда Нобеля (м. Дніпро) \\
\hline 9 & Харківський національний університет імені В.Н. Каразіна \\
\hline 10 & Херсонський державний університет \\
\hline
\end{tabular}

Таблиця 2

Частка навчальних дисциплін нормативної частини циклу професійної підготовки спеціальності «Філологія. Прикладна лінгвістика» у 2019/2020 н. p.

\begin{tabular}{|c|c|c|c|}
\hline № & ФІЛОЛОГІЧНІ & год. & $\%$ \\
\hline 1 & Практичний курс основної іноземної мови & 1290 & 34 \\
\hline 2 & Практичний курс другої іноземної мови & 360 & 9,5 \\
\hline 3 & Практичний курс другої іноземної мови та перекладу & 720 & 19 \\
\hline 4 & Основи прикладної лінгвістики & 90 & 2,4 \\
\hline 5 & Основи теорії перекладу & 90 & 2,4 \\
\hline 6 & Практика перекладу основної іноземної мови & 270 & 7 \\
\hline 7 & Лінгвокраїнознавство & 90 & 2,4 \\
\hline 8 & Комп'ютерна та корпусна лінгвістика & 90 & 2,4 \\
\hline \multirow[t]{2}{*}{9} & Контрастивна типологія & 180 & 4,8 \\
\hline & Всього: & 3180 & 84 \\
\hline № & ІТ-ДИСЦИПЛІНИ & год. & \\
\hline 10 & Основи програмування & 240 & 6 \\
\hline 11 & Веб-дизайн & 90 & 2,4 \\
\hline 12 & Бази даних & 90 & 2,4 \\
\hline 13 & Алгоритми та структури даних & 90 & 2,4 \\
\hline \multirow[t]{3}{*}{14} & Пакети прикладних програм & 90 & 2,4 \\
\hline & Всього: & 600 & 16 \\
\hline & Всього по циклу: & 3780 & 100 \\
\hline
\end{tabular}


ними та IT-дисциплінами становить відповідно 84 i 16\% у нормативній частині (див. табл. 2). Проте ця значуща різниця компенсується у блоках вибору 1 і 2 і становить відповідно 65 i 35\% у блоці 1 та 59 і 41\% у блоці 2 (див. табл. 3). Крім того, вже 3 I курсу деякі дисципліни викладаються студентам іноземною мовою. Вивчення іноземних мов майбутніми прикладними лінгвістами у Державному університеті «Житомирська політехніка» здійснюється за автентичними підручниками, а також за навчальними посібниками високого рівня. Навчальним планом передбачено також опрацювання автентичної художньої, публіцистичної, наукової літератури тощо. Варто зазначити, що $з$ майбутніми прикладними лінгвістами працюють викладачі 3 міжнародною практикою викладання. Все це в комплексі сприяє якісній підготовці фрахівців зі спеціальності «Філологія. Прикладна лінгвістика».

Цикл практичної підготовки складається з таких видів практик, як навчальна, комп'ютерномовленнєва, комп'ютерно-лінгвістична, переддипломна, а також дипломування та захисту випускної бакалаврської роботи. Загальну кількість навчальних годин, відведених на вивчення дисциплін різних циклів, наведено у таблиці 4.

Варто зазначити, що в рамках підготовки таких фрахівців вперше у Житомирській області було введено у навчальний план вивчення китайської мови як фрахової дисципліни, що, безсумнівно, є

Навчальні дисципліни варіативної частини циклу професійної підготовки спеціальності

Таблиця 3 «Філологія. Прикладна лінгвістика» у 2019/2020 н. р.

\begin{tabular}{|c|c|c|c|c|}
\hline № & БЛОК ВИБОРУ 1 & ГОД., \% & БЛОК ВИБОРУ 1 & ГОД., \% \\
\hline & ФІлолОГІЧнІ & & ФІлОлОГІЧнІ & \\
\hline 1 & $\begin{array}{l}\text { Практичний курс сучасної англійської } \\
\text { мови }\end{array}$ & 180 & Сучасна ділова англійська мова & 180 \\
\hline 2 & $\begin{array}{l}\text { Практика фрахового перекладу основної } \\
\text { іноземної мови }\end{array}$ & 180 & Переклад і редагування професійних текстів & 180 \\
\hline 3 & $\begin{array}{l}\text { Практичний курс сучасної англійської } \\
\text { мови та фрахового перекладу }\end{array}$ & 270 & $\begin{array}{l}\text { Сучасна ділова англійська мова та фраховий } \\
\text { переклад }\end{array}$ & 270 \\
\hline 4 & Загальне редагування & 90 & Лінгвістика тексту & 90 \\
\hline 5 & Теорія міжкультурної комунікації & 90 & Основи теорії мовної комунікації & 90 \\
\hline 6 & Медіалінгвістика & 90 & Групова динаміка & 90 \\
\hline \multirow[t]{3}{*}{7} & $\begin{array}{l}\text { Курсова робота з теоретичного курсу } \\
\text { основної іноземної мови }\end{array}$ & 90 & Всього: & $\begin{array}{l}900 \\
59 \%\end{array}$ \\
\hline & Всього: & $\begin{array}{l}990 \\
65 \% \\
\end{array}$ & Іт-дисциплІни & \\
\hline & Іт-дисциплІни & & $\begin{array}{l}\text { Курсова робота з теоретичного курсу інсрор- } \\
\text { маційних технологій }\end{array}$ & 90 \\
\hline 8 & Інтернет-програмування & 90 & Інтернет-програмування: РНР & 90 \\
\hline 9 & Комп’ютерні мережі & 90 & Операційні системи & 90 \\
\hline 10 & Сучасний штучний інтелект & 180 & Інтелектуальні експертні системи & 180 \\
\hline 11 & Математичні основи лінгвістики & 90 & Математичне моделювання в лінгвістиці & 90 \\
\hline \multirow[t]{3}{*}{12} & $\begin{array}{l}\text { Комп'ютерні системи обробки текстової } \\
\text { та графрічної інсрормації }\end{array}$ & 90 & Комунікативна логіка & 90 \\
\hline & Всього: & $\begin{array}{l}\mathbf{5 4 0} \\
35 \%\end{array}$ & Всього: & $\begin{array}{l}630 \\
41 \% \\
\end{array}$ \\
\hline & Всього по блоку вибору 1 & 1530 & Всього по блоку вибору 2 & 1530 \\
\hline
\end{tabular}

Таблиця 4

Частка загальної, профресійної та практичної підготовки у змісті підготовки фрахівців за спеціальністю «Філологія. Прикладна лінгвістика» у 2019/2020 н. р.

\begin{tabular}{|l|c|c|}
\hline \multicolumn{1}{|c|}{ ЦИкли пІдготовки } & (год.) & \% \\
\hline $\begin{array}{l}\text { 1. Цикл загальної підготовки } \\
\text { 1.1. Нормативна частина }\end{array}$ & 1080 & 15 \\
\hline 1.2. Варіативна частина & 270 & 3,8 \\
\hline Усього за циклом загальної підготовки: & 1350 & $\mathbf{1 9}$ \\
\hline $\begin{array}{l}\text { 2. Цикл професійної підготовки } \\
\text { 2.1. Нормативна частина }\end{array}$ & 3780 & 53 \\
\hline 2.2. Варіативна частина & 1530 & 21,5 \\
\hline Усього за циклом професійної підготовки: & $\mathbf{5 3 1 0}$ & $\mathbf{7 5}$ \\
\hline 3. Практична підготовка & $\mathbf{4 5 0}$ & $\mathbf{6 , 3}$ \\
\hline Загальна кількість & 7110 & 100 \\
\hline
\end{tabular}


Фахове вивчення східних, класичних та інших іноземних мов у ЗВо України [3]

\begin{tabular}{|c|c|c|}
\hline № & 3BO & Мова \\
\hline 1 & $\begin{array}{c}\text { Дніпропетровський } \\
\text { національний університет } \\
\text { імені Олеся Гончара }\end{array}$ & $\begin{array}{l}\text { Філологія (китайська) } \\
\text { Філологія (японська) }\end{array}$ \\
\hline 2 & $\begin{array}{l}\text { Київський національний } \\
\text { лінгвістичний університет }\end{array}$ & $\begin{array}{l}\text { «Мова і література» (китайська мова та англійська мова); «Мова і літера- } \\
\text { тура» (японська мова та англійська мова) } \\
\text { «Переклад» (китайська мова та англійська мова); «Переклад» (японська } \\
\text { мова та англійська мова) } \\
\text { «Переклад» (корейська мова та англійська мова); «Переклад» (турецька } \\
\text { мова та англійська мова) } \\
\text { «Переклад» (арабська мова та англійська мова); «Переклад» (перська мова } \\
\text { та англійська мова); } \\
\text { «Переклад» (мова гінді та англійська мова); «Переклад» (в'єтнамська мова } \\
\text { та англійська мова); іврит та друга іноземна мова; «Мова і література» (нідер- } \\
\text { ландська); «Мова і література» (фрінська); «Мова і література» (угорська) }\end{array}$ \\
\hline 3 & $\begin{array}{l}\text { Київський національний } \\
\text { університет імені Тараса } \\
\text { Шевченка }\end{array}$ & $\begin{array}{l}\text { класичні мови (давньогрецька, латинська), іноземна мова; мова та літера- } \\
\text { тура (англійська, іспанська, італійська, німецька, новогрецька, фрранцузька, } \\
\text { шведська), переклад; східні мови та літератури (арабська, гінді, китайська, } \\
\text { корейська, кримськотатарська, перська, турецька, японська), переклад }\end{array}$ \\
\hline 4 & $\begin{array}{l}\text { Київський університет } \\
\text { імені Бориса Грінченка }\end{array}$ & $\begin{array}{l}\text { Філологія. Китайська мова і література } \\
\text { Філологія. Японська мова і література }\end{array}$ \\
\hline 5 & $\begin{array}{l}\text { Львівський національний } \\
\text { університет імені Івана } \\
\text { Франка }\end{array}$ & $\begin{array}{l}\text { Філологія - арабська, перська, японська мова та література і українська } \\
\text { мова та література } \\
\text { Філологія (англійська мова та література та друга іноземна мова). } \\
\text { Філологія (латинська, старогрецька, грецька мова та література та друга } \\
\text { іноземна мова). }\end{array}$ \\
\hline 6 & $\begin{array}{l}\text { Національний педагогічний } \\
\text { університет ім. М. Драгома- } \\
\text { нова }\end{array}$ & $\begin{array}{l}\text { Англійська, китайська; Англійська, турецька } \\
\text { Англійська, арабська; Англійська, японська }\end{array}$ \\
\hline 7 & $\begin{array}{c}\text { Південноукраїнський націо- } \\
\text { нальний педагогічний універ- } \\
\text { ситет імені К.Д. Ушинського } \\
\end{array}$ & Мова і література (англійська)/(китайська)/(німецька) \\
\hline 8 & $\begin{array}{l}\text { Харківський національний } \\
\text { педагогічний університет } \\
\text { імені Григорія Сковороди }\end{array}$ & $\begin{array}{l}\text { Японська мова і література та друга іноземна мова; Китайська мова і літера- } \\
\text { тура та друга іноземна мова } \\
\text { Перська мова і література та друга іноземна мова; Турецька мова і літера- } \\
\text { тура та друга іноземна мова } \\
\text { Іврит та друга іноземна мова }\end{array}$ \\
\hline 9 & $\begin{array}{c}\text { Харківський національний } \\
\text { університет ім. В.Н. Каразіна }\end{array}$ & $\begin{array}{l}\text { Філологія (старогрецька, латинська мова та антична література) } \\
\text { Перекладач китайської мови та літератури }\end{array}$ \\
\hline 10 & $\begin{array}{l}\text { Херсонський державний } \\
\text { університет }\end{array}$ & $\begin{array}{l}\text { Англійська мова і література (спеціалізація: турецька мова) } \\
\text { Російська мова і література (спеціалізація: турецька мова (з поглибленим } \\
\text { вивченням прикладної інорорматики)) }\end{array}$ \\
\hline
\end{tabular}

величезним досягненням адміністрації та профресорсько-викладацького складу університету. Для порівняння наведемо дані про фрахове вивчення східних, класичних та інших іноземних мов у 3 ВО України (див. табл. 5).

Аналіз навчальних планів для підготовки фрахівців із прикладної лінгвістики на 2019-2020 н. р. у Державному університеті «Житомирська політехніка» засвідчив, що при підготовці таких фрахівців на вивчення фрілологічних дисциплін виділяється більше навчального часу, ніж на IT-дисципліни (див. табл. 2). Проте ця різниця збалансовується завдяки дисциплінам, які студент може вивчати на вибір (див. табл. 3). Враховуючи ту обставину, що Державний університет «Житомирська політехніка» $€$ лідером регіону з ІТ-освіти, можна сміливо висловити міркування щодо якісної підготовки фрахівців з прикладної лінгвістики, як фрілологічного її склад- ника, так і інорормаційно-комп'ютерних технологій.

Висновки. Таким чином, можна стверджувати, що завдяки великій кількості навчальних дисциплін за вибором та інтегрованим навчальним курсам на виході ми отримуємо висококваліфікованого фахівця, який володіє кількома іноземними мовами та $є$ компетентним у сорері інорормаційнокомп'ютерних технологій.

\section{БІБЛІОГРАФІЧНИЙ СПИСОК:}

1. Абітурієнт НТУ «ХП|». Освітні програми НТУ «ХП|». 035 - «Філологія. Прикладна лінгвістика» (бакалавр). URL: http://vstup.kpi.kharkov.ua/ edprogram/prykladna-lingvistyka-bakalavr/.

2. Брига Т. Розвиток прикладної лінгвістики як навчальної дисципліни. URL: https://www.cuspu.edu. ua/images/conf-2017-04/s1/1.

3. Гайдай І.О. Підготовка вчителя-срілолога подвійного профрілю у вищих педагогічних навчаль- 
них закладах України (1956 р. - початок XXIст.) : дис. ... канд. пед. наук, Житомир, 2018. 342 с.

4. Державний університет «Житомирська політехніка». Робочі навчальні плани, затверджені Міністерством освіти і науки на 2019-2020 н. р.

5. Корнієнко В.В. Розвиток прикладної лінгвістики у контексті інтеграції наукових галузей. Вісник Національної академії Державної прикордонної служби України імені Богдана Хмельницького. 2011. Вип. 5. URL: http://www.nbuv.gov.ua/e-journals/ Vnadps/2011_5/zmist.html.

6. Лист МОН України № 1/9-736 від 06.12.2007 «Про перелік напрямів (спеціальностей) та їх поєднання 3 додатковими спеціальностями і спеціалізаціями для підготовки педагогічних працівників за освітньо-кваліфрікаційними рівнями бакалавра, спеціаліста, магістра». URL: http://osvita.ua/ legislation/Vishya_osvita/3200/.
7. Наказ МОН України 25.05.2016 № 567 (у редакції наказу МОН України 12.04.2018 № 353) «Перелік спеціалізацій підготовки здобувачів вищої освіти ступенів бакалавра та магістра за спеціальністю 035 “Філологія", за якими здійснюється фрормування та розміщення державного замовлення». URL: https://zakon.rada.gov.ua/laws/show/z0825-16.

8. Соколова І.В. Теоретичні та методичні основи профресійної підготовки майбутнього вчителя за двома спеціальностями на фрілологічних факультетах вищих навчальних закладів : авторефр. дис. ... докт. пед. наук, Київ, 2008. 44 с.

9. Сосяк М.М. Управлінські аспекти організації навчального процесу 3 другої іноземної мови у педагогічних університетах. Іноземні мови. 2001. № 1. c. 23-26.

10.Шторгин В.М. Навчальні заклади України : довідник. Київ : «Феміна», 1996. 